\title{
The marine brooder Excirolana braziliensis (Crustacea: Isopoda) is also a complex of cryptic species on the coast of Chile
}

\author{
El isópodo marino Excirolana braziliensis (Crustacea: Isopoda) es también un complejo de \\ especies crípticas en la costa de Chile
}

\author{
ANDREA I. VARELA ${ }^{1, ~ *} \&$ PILAR A. HAYE \\ Departamento de Biología Marina, Facultad de Ciencias del Mar, Universidad Católica del Norte, Larrondo 1281, Coquimbo, \\ Chile, y Centro de Estudios Avanzados en Zonas Áridas (CEAZA), Coquimbo, Chile \\ ${ }_{1}^{1}$ Present address: School of Biological Sciences, PO Box 600, Victoria University of Wellington, New Zealand \\ ${ }^{*}$ Corresponding author: and.vrl@gmail.com
}

\begin{abstract}
Speciation is a direct consequence of isolated populations in taxa with low dispersal potential. The brooding crustacean Excirolana braziliensis, with a presumably wide geographic range of distribution $\left(\sim 16^{\circ} \mathrm{N}-41^{\circ} \mathrm{S}\right.$ in the Pacific and $\sim 19^{\circ} \mathrm{N}-35^{\circ} \mathrm{S}$ in the Atlantic), has been detected to correspond to cryptic species on the coast of Panama. Latitudinal variations in reproductive features in E. braziliensis have been attributed to phenotypic plasticity, however, the differences may be the result of divergent populations. Considering that the taxon has been reported to be a complex of cryptic species in other geographic areas and given the phenotypic differences detected along its distribution range, we hypothesized that $E$. braziliensis is a complex of species in the coast of Chile. We used partial cytochrome c oxidase subunit I (COI) sequences from 132 individuals with the diagnostic morphology of E. braziliensis collected along $\sim 2200 \mathrm{~km}$ of coast to determine the genetic structure of E. braziliensis. Phylogenetic and phylogeographic analyses showed three distinct clades with 14 to $19 \%$ of genetic divergence and high values of genetic differentiation. Intra and inter-clade divergence revealed the existence of a species complex of $E$. braziliensis on the coast of Chile, supporting growing evidence of the high abundance of cryptic species in marine invertebrate taxa.
\end{abstract}

Key words: cryptic species, genetic differentiation, genetic distance, marine peracarids, phylogenetics.

\section{RESUMEN}

La especiación es una consecuencia directa de poblaciones aisladas en taxa con bajo potencial de dispersión. El crustáceo incubador Excirolana braziliensis tiene un rango de distribución presumiblemente amplio $\left(\sim 16^{\circ} \mathrm{N}-41^{\circ} \mathrm{S}\right.$ en el Pacífico y $\sim 19^{\circ} \mathrm{N}-35^{\circ} \mathrm{S}$ en el Atlántico). Se ha detectado que este taxón representa un complejo de especies crípticas en la costa de Panamá. Variaciones latitudinales en características reproductivas en E. braziliensis han sido atribuidas a plasticidad fenotípica, sin embargo, las diferencias podrían deberse a la existencia de poblaciones divergentes. Considerando que se ha reportado que este taxón es un complejo de especies crípticas en otras áreas geográficas y dadas las diferencias fenotípicas detectadas a lo largo de su rango de distribución, hipotetizamos que E. braziliensis es un complejo de especies en la costa de Chile. Utilizamos secuencias parciales del gen citocromo c oxidasa subunidad I (COI) de 132 individuos con la morfología diagnóstica de E. braziliensis recolectados a lo largo de $\sim 2200 \mathrm{~km}$ de costa para determinar la estructura genética de E. braziliensis. Análisis filogenéticos y filogeográficos revelaron tres clados que presentaron una divergencia genética entre 14-19 \% y valores de diferenciación altos. La divergencia intra e interclados indican que existe un complejo de especies de E. braziliensis en la costa de Chile, lo que se suma a la creciente evidencia de la alta abundancia de especies crípticas en invertebrados marinos.

Palabras clave: diferenciación genética, distancia genética, especies crípticas, filogenia, peracáridos marinos.

\section{INTRODUCTION}

Cryptic species are species that are difficult to recognize based in morphology (Knowlton 1993, Bickford et al. 2007). While 'sibling species' may refer specifically to cryptic species that share a common ancestor, the term is usually considered a synonymous of 'cryptic species' (reviewed by Bickford et al. 2007). The abundance of cryptic species discoveries reflects a lack of morphological divergence or an inadequate knowledge of 
the morphological differences of divergent groups. Information provided by morphology is limited by our poor understanding of functional morphology, which is strongly influenced by natural selection (Knowlton 1993, Bickford et al. 2007). Moreover, morphological stasis can be promoted by stabilizing or convergent selection under extreme environmental conditions (Bickford et al. 2007). Research to uncover cryptic species complexes can have serious implications for evolutionary biology and for management and conservation plans; for example, the discovery of cryptic species in a particular habitat might reveal underscored levels of diversity and/or endemism upgrading the priority level for conservation for that habitat (reviewed by Bickford et al. 2007). Complexes of sibling species and cryptic species have been widely identified using DNA markers (e.g., Gouws et al. 2004, Moura et al. 2008, Jordaens et al. 2010, Azuma et al. 2011), and most cryptic species are marine invertebrates (Knowlton 1993). Cryptic species have been reported along the geographic range that was assumed for one benthic marine species with low dispersal potential (Held \& Wägele 2005, Raupach \& Wägele 2006, Remerie et al. 2006, Linse et al. 2007, Raupach et al. 2007, Boissin et al. 2008, Baird et al. 2011, Carr et al. 2011, Doellman et al. 2011). Under a low dispersal scenario, isolation by distance and outbreeding depression are enough to account for a high speciation rate (Hoelzer et al. 2008). Many marine brooders may have an enhanced speciation potential given their small body size and low vagility, resulting in low potential for active dispersal (Teske et al. 2007).

Peracarids are a group of direct developing crustaceans that brood their larvae up to a crawl-away stage. For some peracarids longdistance dispersal may occur through rafting on floating substrata such as detached macroalgae (Thiel \& Haye 2006), or via anthropogenic transfer (e.g., Wittmann \& Ariani 2009). Other peracarid species, however, live in habitats that are not suitable for alternative dispersal mechanisms, for example, the abundant amount of species that live in soft bottom sandy beaches, cannot survive on floating objects (Thiel \& Gutow 2005). Occasional dispersal events between beaches may occur if individuals remain attached to its prey (e.g., live fish) for enough time to complete a passive transport (Sponer \& Lessios 2009). Similarly, marine birds may occasionally transport individuals if they casually remain attached to their plumage or feet, as reported for aquatic non-marine invertebrates (Frisch et al. 2007). These stochastic long-distance dispersal events are likely to be infrequent not allowing for sufficient gene flow to counterbalance the effects of genetic drift. Therefore, the wide range of geographic distribution reported for many soft-bottom peracarids may be the result of undetected species complexes.

The beach dwelling isopod Excirolana braziliensis Richardson has a wide geographic range in America and Chile. It has been found in the Pacific Ocean from the Gulf of California in Mexico (Dexter 1976) to Chiloé Island in southern Chile (Jaramillo et al. 2000). In the Atlantic Ocean it has been reported from the Gulf of Mexico (Dexter 1976) to Uruguay (Defeo et al. 1997). For the coast of Panama Lessios \& Weinberg (1994) and Sponer \& Lessios (2009) reported three divergent lineages in E. braziliensis, indicating the presence of a species complex. Along the coast of Chile E. braziliensis has been scarcely studied. A highlight is the study of Cardoso \& Defeo (2003); they found strong latitudinal variations in reproductive features in populations of $E$. braziliensis from the Pacific and Atlantic Oceans. Even though the authors attributed the variations to phenotypic plasticity, the phenotypic divergence could also be a consequence of genetic differentiation between local populations.

Given the likelihood of speciation in taxa with low active and passive dispersal potential, the presence of a species complex of $E$. braziliensis on the coast of Panama and the phenotypic variation detected among populations, we hypothesized that there is a species complex in E. braziliensis in the Chilean coast. For this, the genetic structure between local populations of $E$. braziliensis along the north-central coast of Chile was analyzed using cytochrome c oxidase subunit I (COI) sequences.

\section{METHODS}

\section{Sampling, DNA extraction, PCR and sequencing}

Samples were collected from seven localities of the Chilean coast influenced by the Humboldt Current 
System (from $18.4^{\circ} \mathrm{S}$ to $38.2^{\circ} \mathrm{S}$, along $\sim 2200 \mathrm{~km}$ ) (Table 1, Fig. 1A). During low tide, macroinfaunal species were washed out of bulk sand samples with $2 \mathrm{~mm}$ mesh size bags. Excirolana species are easily and clearly distinguishable from other macroinfaunal isopods of sandy beaches (Jaramillo et al. 1998). Samples were were preserved in $95 \%$ ethanol at $-20^{\circ} \mathrm{C}$ until DNA extraction.

Of the three species of the genus Excirolana present along the Chilean coast, E. braziliensis can be easily distinguished from the others (E. hirsuticauda and $E$. monodi) by the shape of the cephalon and the telson, as well as by the length of the antennae. In E. braziliensis the cephalon width is three times the length, the telson has a rounded apex, antenna 1 reaches half of pereonite 3 , and antenna 2 extends until the end of pereonite 5 (Jaramillo 1982). All individuals used in this study had the diagnostic characteristics of E. braziliensis (Jaramillo 1982).

Depending on the availability, seven to 22 individuals of $E$. braziliensis per locality were analyzed (Table 1 ). Whole individuals were used for the DNA extraction; except for individuals larger than $5 \mathrm{~mm}$ for which only telson muscle was used. Genomic DNA was extracted with Qiagen's QIAamp DNA mini kit following manufacturer's instructions.

We used the COI gene to detect population genetic structure. This marker has been extensively validated as a good species marker for most animal species, and it is the preferred marker for DNA Barcoding in many animal groups including crustaceans (e.g., Bucklin et al. 2011, Havermans et al. 2011). Sponer \& Lessios (2009) also used COI and could easily distinguish the clades that comprise the species complex of $E$. braziliensis in the coast of Panama.

A partial sequence of the COI gene was amplified with PCR using the primers HCO2198 and LCO1490 (Folmer et al. 1994). PCR's were carried out with 1X PCR buffer, $2 \mathrm{mM} \mathrm{MgCl}_{2}, 0.4 \mu \mathrm{M}$ of each primer, 0.2

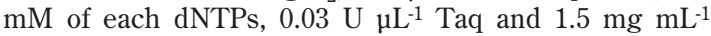
Bovine Serum Albumin (BSA), $1 \mu \mathrm{L}$ of template DNA $(\sim 20 \mathrm{ng})$ and distilled $\mathrm{H}_{2} \mathrm{O}$ to complete final volume. The cycling conditions were: initial denaturing of $94{ }^{\circ} \mathrm{C}$ for 10 min followed by 35 cycles of 1 min denaturing at $94{ }^{\circ} \mathrm{C}, 1 \mathrm{~min}$ annealing at $51{ }^{\circ} \mathrm{C}$ and 2 min extension at $72{ }^{\circ} \mathrm{C}$, and ending with a final extension at $72^{\circ} \mathrm{C}$ by 13 min. Amplicons were purified by adding $28.8 \mu \mathrm{L}$ Shrimp Alkaline Phosphatase and $7.2 \mu \mathrm{L}$ of Exonuclease I to $45 \mu \mathrm{L}$ PCR product followed by incubation at $37^{\circ} \mathrm{C}$ for
$15 \mathrm{~min}$ and $80{ }^{\circ} \mathrm{C}$ for $15 \mathrm{~min}$. Purified products were sequenced in both directions with an ABI 3730XL capillary automated sequencer.

CODONCODE Aligner 1.2.0 (CodonCode) was used to inspect chromatographs for ambiguous sites, obtain consensus sequences, and for sequence alignment. Alignment was verified through translation to amino acids. Sequences were submitted to GenBank (Accession Numbers: FJ541198-FJ541243).

\section{Data analyses}

Two sequences of $E$. hirsuticauda (Genbank Accession Numbers: FJ532105 and FJ532142) were used as outgroup taxa for phylogenetic analyses. Phylogenetic hypotheses were searched performing Maximum Likelihood Analysis (MLA), and Bayesian Analysis (BA), implemented in PAUP 4.b10 (Swofford 2002) and MrBayes 3.1.2 (Ronquist \& Huelsenbeck 2003), respectively. The model of DNA evolution that better fit the data according to jModelTest 0.1.1 (Posada 2008) was Hasegawa-Kishino-Yano plus gamma $(\mathrm{HKY}+\mathrm{G})$, and was used for MLA and BA. A bootstrap analysis with 10000 replicates was used to obtain support values for the nodes for the MLA using PAUP. In the BA, posterior probability values for the nodes were obtained using 5000000 iterations and sampling every 10 generations. Two simultaneous and independent analyses were run until the standard deviation of split frequencies was below 0.01 . The first $25 \%$ of saved trees were discarded as burn-in.

The mutational relationships between all haplotypes detected were visualized with a median joining haplotype network generated using NETWORK 4.5 (Bandelt et al. 1999). Ambiguous loops in the network were resolved using the criteria of Crandall \& Templeton (1993). The genetic $\mathrm{p}$ distance among haplotypes was calculated with PAUP*4.b10. Pairwise $F_{S T}$ values between localities were calculated in ARLEQUIN 3.11 (Excoffier et al. 2005). The significance of the $\mathrm{F}_{\mathrm{ST}}$ values was evaluated by 10000 permutations.

\section{RESULTS}

Sequences of 583 base pairs were obtained for 132 individuals from seven localities of the Chilean coast (Table 1, Fig. 1A). The MLA

TABLE 1

Number of individuals of Excirolana braziliensis analyzed in each locality of the Chilean coast.

Número de individuos de Excirolana braziliensis analizados en cada localidad de la costa de Chile.

\begin{tabular}{lccc}
\hline Locality & Code & Coordinates & Number of individuals \\
\hline Arica & Ari & $18.4^{\circ} \mathrm{S}-70.3^{\circ} \mathrm{W}$ & 7 \\
Playa Chipana & Chi & $21.3^{\circ} \mathrm{S}-70.1^{\circ} \mathrm{W}$ & 20 \\
Península Cangrejo & Pca & $24.4^{\circ} \mathrm{S}-70.6^{\circ} \mathrm{W}$ & 22 \\
Caldera & Cad & $27.0^{\circ} \mathrm{S}-70.8^{\circ} \mathrm{W}$ & 20 \\
Puerto Aldea & Pal & $30.3^{\circ} \mathrm{S}-71.2^{\circ} \mathrm{W}$ & 19 \\
Playa Pangua & Pan & $34.5^{\circ} \mathrm{S}-72.0^{\circ} \mathrm{W}$ & 22 \\
Playa Queule & Que & $38.2^{\circ} \mathrm{S}-73.6^{\circ} \mathrm{W}$ & 22 \\
Total & & & 132 \\
\hline
\end{tabular}


A

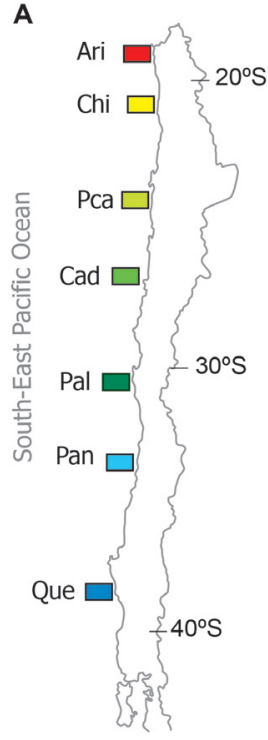

B

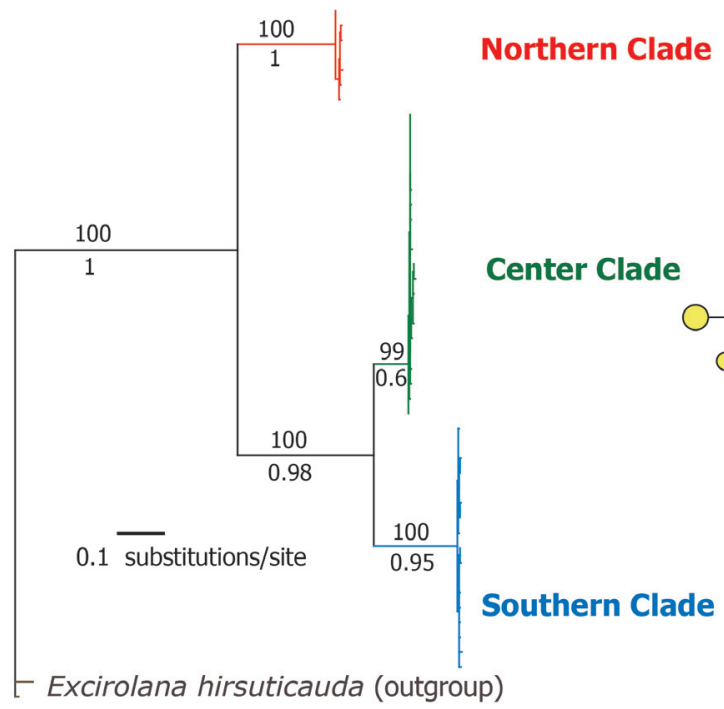

C

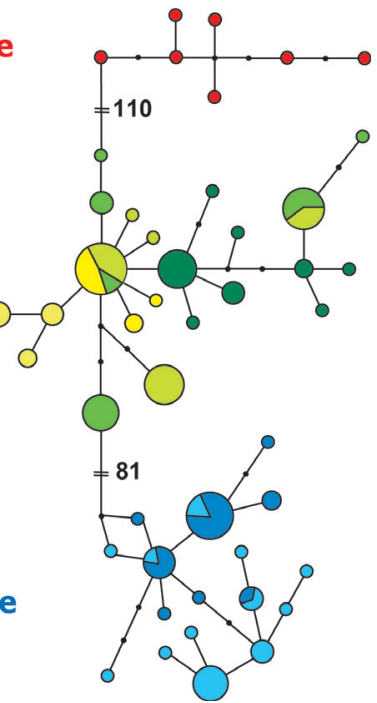

Fig. 1: Partial map of Chile (South-East Pacific coast) showing the localities where E. braziliensis were sampled (A). Maximum Likelihood phylogram of $45 \mathrm{COI}$ haplotypes of $E$. braziliensis (B). Median joining haplotype network of E. braziliensis (C). In the phylogram, values above the branches correspond to Maximum Likelihood bootstrap and values below to Bayesian posterior probabilities values. Colors in the phylogram and haplotype network represent the different localities shown in the map (A). The symbol\|indicates that the line was truncated and the numbers next to show the number of mutational steps between groups of haplotypes.

Mapa parcial de Chile (Pacífico Sur Este) indicando las localidades donde se recolectaron las muestras de E. braziliensis (A). Filograma de Máxima Verosimilitud de los 45 haplotipos de E. braziliensis (B). Red de haplotipos de E. braziliensis construida con el método "median joining" (C). En el filograma, los valores sobre las ramas corresponden a los valores de iteraciones obtenidos con Máxima Verosimilitud y los valores bajo las ramas a probabilidades posteriores Bayesianas. Los colores en el filograma y en la red de haplotipos representan las diferentes localidades indicadas en el mapa (A). El símbolo \|indica que la línea fue truncada y los números al lado de indican el número de pasos mutacionales entre los grupos de haplotipos.

and BA phylogenetic analyses revealed three highly divergent clades of $E$. braziliensis, each with reciprocal monophyly, that are here on referred to as Northern Clade, Center Clade, and Southern Clade (Fig. $1 \mathrm{~A}$ and $1 \mathrm{~B}$ ). The phylogenetic hypotheses derived from MLA and BA only differed in the position of the terminal nodes within clades (haplotypes that differed on one nucleotide) with low bootstrap support values.

Consistent with phylogenetic analyses, the arrangement of the 45 haplotypes in the median joining haplotype network shows three distinct haplogroups, each corresponding to the clades detected on the phylogenetic analyses (Fig. 1C). The Northern Clade was found in Arica $\left(18.4^{\circ} \mathrm{S}\right)$, the Center Clade from Chipana $\left(21.3^{\circ}\right.$ S) to Puerto Aldea $\left(30.3^{\circ} \mathrm{S}\right)$, and the Southern Clade in Pangua $\left(34.5^{\circ} \mathrm{S}\right)$ and Queule $\left(38.2^{\circ} \mathrm{S}\right)$ (Fig. 1A and 1B).
The Northern and Center clades are separated by 110 mutational steps and have $18 \%$ of genetic divergence. The Center and Southern clades are separated by 81 mutational steps and have $14 \%$ of genetic divergence. Northern and Southern clades diverge in $19 \%$. While the Northern Clade was represented by only one locality, the genetic divergence within the Center clade ranged from $0.45 \%$ to $0.67 \%$ and was $0.66 \%$ for the Southern Clade.

Pairwise $\mathrm{F}_{\mathrm{ST}}$ values between localities from the three clades were close to 1.0 and highly significant $(\mathrm{P}<0.0001)$ (Table 2$)$, indicating almost complete genetic differentiation between clades. Intra-clade divergence was evaluated for the Center and Southern clades, which had more than one location included in the study; both Center and Southern clades had significant intra-clade population-pairwise $F_{S T}$ values $(P<0.001)$, however, genetic 
TABLE 2

Pairwise $\mathrm{F}_{\mathrm{ST}}$ values between localities. Values between localities from the different clades are indicated by "A". All the other correspond to the values between localities within Center and Southern Clades. All the values were significant $(\mathrm{P}<0.001)$. Codes as in Table 1.

Valores de $\mathrm{F}_{\mathrm{ST}}$ entre localidades. Los valores entre localidades de los diferentes clados están indicados por "A". Todos los otros corresponden a los valores entre localidades dentro de los clados Centro y Sur. Todos los valores fueron significativos $(\mathrm{P}<0.001)$. Las siglas representan localidades como se muestra en la Tabla 1.

\begin{tabular}{lcccccc}
\hline & Ari & Chi & Pca & Cad & Pal & Pan \\
\hline Chi & $0.984^{\mathrm{A}}$ & & & & & \\
Pca & $0.975^{\mathrm{A}}$ & 0.277 & & & & \\
Cad & $0.969^{\mathrm{A}}$ & 0.268 & 0.158 & & & \\
Pal & $0.979^{\mathrm{A}}$ & 0.444 & 0.380 & 0.328 & & \\
Pan & $0.974^{\mathrm{A}}$ & $0.975^{\mathrm{A}}$ & $0.967^{\mathrm{A}}$ & $0.963^{\mathrm{A}}$ & $0.971^{\mathrm{A}}$ & \\
Que & $0.984^{\mathrm{A}}$ & $0.983^{\mathrm{A}}$ & $0.976^{\mathrm{A}}$ & $0.972^{\mathrm{A}}$ & $0.980^{\mathrm{A}}$ & 0.460 \\
\hline
\end{tabular}

differentiation between localities within clades was less than half than between clades (Table 2).

\section{DISCUSSION}

As hypothesized, COI sequence analyses revealed that the wide range of geographic distribution of the brooder E. braziliensis along the north-central Chilean coast is explained by the presence of a species complex. The low dispersal potential of Excirolana species, together with their small body size and concomitant low intrinsic dispersal have led to three highly divergent lineages between 18 and $38^{\circ} \mathrm{S}$ on the South-East Pacific coast under the influence of the Humboldt Current System.

The genetic divergence among clades of $E$. braziliensis ranged from $14 \%$ to $19 \%$, while the divergence within clades was very low $(<0.67 \%)$. Comparisons of species of the family Cirolanidae revealed a sequence divergence from $13.6 \%$ to $14.7 \%$ (Wetzer 2001). Other studies comparing species within a genus of peracarids have led to similar or slightly higher values. For the genus Idotea, Wares (2001) determined a genetic divergence of 17-25\%; Markow \& Pfeiler (2010) reported divergences from $14.9 \%$ to $30.3 \%$ among species of Ligia, including terrestrial and marine-terrestrial species; for the amphipod genus Eusirus interclade distances fell between 4.6 to 10.9 \% (Baird et al. 2011); and Baratti et al. (2005) suggested that
Sphaeroma terebrans was a complex of cryptic species with genetic distances of 15 to $18 \%$. The high values of genetic divergence among clades detected within $E$. braziliensis were close to the divergence of the COI gene generally reported between species. When genetic divergence between clades exceeds the typical values for congeners it is reasonable to infer there are sibling/cryptic species. Therefore, the detected levels of genetic divergence between clades whose individuals have the diagnostic features of $E$. braziliensis suggest that there is a complex of cryptic species under the formal taxon E. braziliensis on the Chilean coast, as had been shown for the coasts of Panama (Lessios \& Weinberg 1994, Sponer \& Lessios 2009). So far, few studies have identified marine cryptic species on the Chilean coast. Using morphological, developmental and genetics features, Véliz et al. (2003) found three cryptic species of Crepidula from northern Chile. Later, Tellier et al. (2009) identified two divergent lineages of the kelp Lessonia nigrescens at $30^{\circ} \mathrm{S}$ that likely evolved through parapatric speciation. Recently, Montecinos et al. (2012) detected three highly divergent clades along the Chilean coast in the red alga Mazzaella laminarioides, which likely correspond to cryptic species. Further studies are needed to reveal the possible existence of other cryptic species on the Chilean coast.

The results of this study provide insights into a former study of $E$. braziliensis performed by Cardoso \& Defeo (2003). They found that 
individuals from two distant local populations (at 23 and $39^{\circ} \mathrm{S}$ ) of E. braziliensis had differences in their breeding and recruitment seasons, fecundity, and size of mature females and juveniles. According to our results, individuals from these two locations correspond to different clades, suggesting that the differences in reproductive features most likely reflect differences between two species and not within species phenotypic plasticity. Additional morphological analyses should aid in determining intra and inter-clade morphological variability of the $E$. braziliensis species complex on the coast of Chile. Lessios \& Weinberg (1994) found that body length, body width, eye diameter and length of antennule were important characters to delimit species of the E. braziliensis complex in Panama and should also assist in morphological delimitation of E. braziliensis species on the Chilean coast. It is necessary to integrate and combine different sources of evidence, e.g. morphology, reproductive characteristics, and phylogenetics, to evaluate the taxonomic status of marine species biodiversity (Castro-Longoria et al. 2003, Padial et al. 2009). Target taxa should be those with low intrinsic and extrinsic dispersal potential that have a large geographic range reported, as is the case of E. braziliensis and other beach dwelling peracarids.

Within the detected lineages of $E$. braziliensis there was a high and significant genetic differentiation. Similarly, other marine taxa with low dispersal potential show high and significant genetic differentiation, such as the Atlantic clade of the mysid Mesopodopsis slabberi (Remerie et al. 2006), and Mediterranean clades of the brooding brittle star, Amphipholis squamata (Boissin et al. 2008). High levels of genetic differentiation within clades or species seem to be a common pattern in marine brooders, and may reflect an ongoing process of speciation.

In conclusion, $E$. braziliensis from the Chilean coast shows a similar genetic pattern to that detected in Panama for this species, for others isopods worldwide, and for few marine taxa from the Chilean coast. There are highly divergent clades that most likely correspond to a complex of cryptic species. Our study supports growing evidence of the high abundance of cryptic species within marine invertebrate taxa. Further studies in other geographic areas where E. braziliensis is found (e.g., between Panama and Chile) are required to determine the number of cryptic species that make up the complex and how are they distributed in the Atlantic and Pacific coast.

ACKNOWLEDGMENTS: We thank Martin Thiel, Iván Hinojosa, Leonardo Miranda and Rodrigo Rojas for help with sample collection and Raúl Vera for help with DNA extractions. Chilean FONDECYT grant number 1090670 supported this study.

\section{LITERATURE CITED}

AZUMA N, T YAMASAKI \& S CHIBA (2011) Mitochondrial and nuclear DNA analysis revealed a cryptic species and genetic introgression in Littorina sitkana (Mollusca, Gastropoda). Genetica 139: 1399-1408.

BAIRD HP, KJ MILLER \& JS STARK (2011) Evidence of hidden biodiversity, ongoing speciation and diverse patterns of genetic structure in giant Antarctic amphipods. Molecular Ecology 20: 34393454 .

BANDELT HJ, P FORSTER \& A RÖHL (1999) Medianjoining networks for inferring intraspecific phylogenies. Molecular Biology and Evolution 16: $37-48$.

BARATTI M, E GOTI \& G MESSANA (2005) High level of genetic differentiation in the marine isopod Sphaeroma terebrans (Crustacea: Isopoda: Sphaeromatidae) as inferred by mitochondrial DNA analysis. Journal of Experimental Marine Biology and Ecology 315: 225-234.

BICKFORD D, DJ LOHMAN, NS SODHI, PKL NG, $R$ MEIER, K WINKER, KK INGRAM \& I DAS (2007) Cryptic species as a window on diversity and conservation. Trends in Ecology and Evolution 22: 148-155.

BOISSIN E, JP FÉRAL \& A CHENUIL (2008) Defining reproductively isolated units in a cryptic and syntopic species complex using mitochondrial and nuclear markers: The brooding brittle star, Amphipholis squamata (Ophiuroidea). Molecular Ecology 17: 1732-1744.

BUCKLIN A, D STEINKE \& L BLANCO-BERCIAL (2011) DNA Barcoding of marine metazoa. Annual Review of Marine Science 3: 471-508.

CARDOSO RS \& O DEFEO (2003) Geographical patterns in reproductive biology of the PanAmerican sandy beach isopod Excirolana braziliensis. Marine Biology 143: 573-581.

CARR CM, SM HARDY, TM BROWN, TA MACDONALD \& PDN HEBERT (2011) A trioceanic perspective: DNA barcoding reveals geographic structure and cryptic diversity in Canadian polychaetes. PLoS ONE 6: e22232.

CASTRO-LONGORIA E, J ÁLVAREZ-BORREGO, A ROCHA-OLIVARES, S GÓMEZ \& V KOBER (2003) Power of a multidisciplinary approach: Use of morphological, molecular and digital methods in the study of harpacticoid cryptic species. Marine Ecology Progress Series 249: 297-303.

CRANDALL KA \& AR TEMPLETON (1993) Empirical tests of some predictions from coalescent theory 
with applications to intraespecific phylogeny reconstruction. Genetics 134: 959-969.

DEFEO O, A BRAZEIRO, A DE ALAVA \& G RIESTRA (1997) Is sandy beach macrofauna only physically controled? Role of substrate and competition in isopods. Estuarine, Coastal and Shelf Science 45: 453-462.

DEXTER D (1976) The sandy-beach fauna of Mexico. The Southwestern Naturalist 20: 479-485.

DOELLMAN MM, GC TRUSSELL, JW GRAHAME \& SV VOLLMER (2011) Phylogeographic analysis reveals a deep lineage split within North Atlantic Littorina saxatilis. Proceedings of the Royal Society B 278: 3175-3183.

EXCOFFIER L, G LAVAL \& S SCHNEIDER (2005) Arlequin (version 3.0): An integrated software package for population genetics data analysis. Evolutionary Bioinformatics Online 1: 47-50.

FOLMER O, M BLACK, R HOEH, RA LUTZ \& R VRIJENHOEK (1994) DNA primers for amplification of mitochondrial cytochrome c oxydase subunit I from diverse metazoan invertebrates. Molecular Marine Biology and Biotechnology 3: 294-299.

FRISCH D, AJ GREEN \& J FIGUEROLA (2007) High dispersal capacity of a broad spectrum of aquatic invertebrates via waterbirds. Aquatic Sciences 69: 568-574.

GOUWS G, BA STEWART \& SR DANIELS (2004) Cryptic species within the freshwater isopod Mesamphisopus capensis (Phreatoicidea: Amphisopodidae) in the Western Cape, South Africa: Allozyme and 12S rRNA sequence data and morphometric evidence. Biological Journal of the Linnean Society 81: 235-253.

HAVERMANS C, ZT NAGY, G SONET, C DE BROYER \& P MARTIN (2011) DNA barcoding reveals new insights into the diversity of Antarctic species of Orchomene sensu lato (Crustacea: Amphipoda: Lysianassoidea). Deep-Sea Research II 58: 230241.

HELD C \& JW WÄGELE (2005) Cryptic speciation in the giant Antarctic isopod Glyptonotus antarcticus (Isopoda: Valvifera: Chaetiliidae). Scientia Marina 69: 175-181.

HOELZER GA, R DREWES, J MEIER \& R DOURSAT (2008) Isolation-by-Distance and outbreeding depression are sufficient to drive parapatric speciation in the absence of environmental influences. PLoS Computational Biology 4: e1000126.

JARAMILLO E (1982) Taxonomy, natural history and zoogeography of sand beach isopods from the coast of southern Chile. Studies on Neotropical Fauna and Environment 17: 175-194.

JARAMILLO E, F CARRASCO, P QUIJÓN, M PINO \& H CONTRERAS (1998) Distribution and community structure of the benthic macroinfauna at the coast of northern Chile. Revista Chilena de Historia Natural 71: 459-478.

JARAMILLO E, C DUARTE \& H CONTRERAS (2000) Sandy beach macroinfauna from the coast of Ancud, Isla de Chiloé, southern Chile. Revista Chilena de Historia Natural 73: 771-786.

JORDAENS K, J PINCEEL, N VAN HOUTTE, K BREUGELMANS \& T BACKELJAU (2010) Arion transsylvanus (Mollusca: Pulmonata: Arionidae): Rediscovery of a cryptic species. Zoologica Scripta 39: 343-362.
KNOWLTON N (1993) Sibling species in the sea. Annual Review of Ecology and Systematics 24: 189-216.

LESSIOS HA \& JR WEINBERG (1994) Genetic and morphological divergence among morphotypes of the isopod Excirolana on the two sides of the Isthmus of Panama. Evolution 48: 530-548.

LINSE K, T COPE, A LÖRZ \& C SANDS (2007) Is the Scotia Sea a centre of Antarctic marine diversification? Some evidence of cryptic speciation in the circum-Antarctic bivalve Lissarca notorcadensis (Arcoidea: Philobryidae). Polar Biology 30: 1059-1068.

MARKOW TA \& E PFEILER (2010) Mitochondrial DNA evidence for deep genetic divergences in allopatric populations of the rocky intertidal isopod Ligia occidentalis from the eastern Pacific. Molecular Phylogenetics and Evolution 56: 468473

MONTECINOS A, BR BROITMAN, S FAUGERON, PA HAYE, F TELLIER \& ML GUILLEMIN (2012). Species replacement along a linear coastal habitat: Phylogeography and speciation in the red alga Mazzaella laminarioides along the south east pacific. BMC Evolutionary Biology 12: 97.

MOURA CJ, DJ HARRIS, MR CUNHA \& AD ROGERS (2008) DNA barcoding reveals cryptic diversity in marine hydroids (Cnidaria: Hydrozoa) from coastal and deep-sea environments. Zoologica Scripta 37: 93-108.

PADIAL JM, S CASTROVIEJO-FISHER, J KÖHLER, $C$ VILÀ, JC CHAPARRO \& I DE LA RIVA (2009) Deciphering the products of evolution at the species level: The need for an integrative taxonomy. Zoologica Scripta 38: 431-447.

POSADA D (2008) jModelTest: Phylogenetic model averaging. Molecular Biology and Evolution 25: 1253-1256.

RAUPACH M \& JW WÄGELE (2006) Distinguishing cryptic species in Antarctic Asellota (Crustacea: Isopoda) - A preliminary study of mitochondrial DNA in Acanthaspidia drygalskii. Antarctic Science 18: 191-198.

RAUPACH M, M MALYUTINA, A BRANDT \& JW WÄGELE (2007) Molecular data reveal a highly diverse species flock within the munnopsoid deepsea isopod Betamorpha fusiformis (Barnard, 1920) (Crustacea: Isopoda: Asellota) in the Southern Ocean. Deep-Sea Research II 54: 1820-1830.

REMERIE T, T BOURGOIS, D PEELAERS, A VIERSTRAETE, J VANFLETEREN \& A VANREUSEL (2006) Phylogeographic patterns of the mysid Mesopodopsis slabberi (Crustacea: Mysida) in Western Europe: Evidence for high molecular diversity and cryptic speciation. Marine Biology 149: 465-481.

RONQUIST F \& JP HUELSENBECK (2003) MRBAYES 3: Bayesian phylogenetic inference under mixed models. Bioinformatics 19: 1572-1574.

SPOONER R \& HA LESSIOS (2009) Mitochondrial phylogeography of the intertidal isopod Excirolana braziliensis on the two sides of the Isthmus of Panama. Proceedings of the Smithsonian Marine Science Symposium 38: 219228.

SWOFFORD DL (2002) PAUP*: Phylogenetic analysis using parsimony (* and other methods). Version 4.b10. Sinauer Associates, Sunderland, Massachusetts.

TELLIER F, AP MEYNARD, JA CORREA, S FAUGERON \& M VALERO (2009) Phylogeographic analyses 
of the $30^{\circ} \mathrm{S}$ south-east Pacific biogeographic transition zone establish the occurrence of a sharp genetic discontinuity in the kelp Lessonia nigrescens: Vicariance or parapatry? Molecular Phylogenetics and Evolution 53: 679-693.

TESKE PR, I PAPADOPOULOS, GI ZARDI, CD MCQUAID, MT EDKINS, CL GRIFFITHS \& NP BARKER (2007) Implications of life history for genetic structure and migration rates of southern African coastal invertebrates: Planktonic, abbreviated and direct development. Marine Biology 152: 697-711.

THIEL M \& L GUTOW (2005) The ecology of rafting in the marine environment. II. The rafting organisms and community. Oceanography and Marine Biology: An Annual Review 43: 279-418.

THIEL M \& PA HAYE (2006) The Ecology of rafting in the marine environment. III. Biogeographical and evolutionary consequences. Oceanography and Marine Biology: An Annual Review 44: 323-429.

VÉLIZ D, FM WINKLER \& C GUISADO (2003) Developmental and genetic evidence for the existence of three morphologically cryptic species of Crepidula in northern Chile. Marine Biology 143: $131-142$

WARES JP (2001) Intraespecific variation and geographic isolation in Idotea balthica (Isopoda: Valvifera). Journal of Crustacean Biology 21: 1007-1013.

WETZER R (2001) Hierarchical analysis of mtDNA variation and the use of mtDNA for isopod (Crustacea: Peracarida: Isopoda) systematics. Contributions to Zoology 70: 23-39.

WITTMANN KJ \& AP ARIANI (2009) Reappraisal and range extension of non-indigenous Mysidae (Crustacea, Mysida) in continental and coastal waters of eastern France. Biological Invasions 11: 401-407. 